\title{
The Effect of Rosmarinic Acid on Cell Viability, Steatosis, Paraoxonase-1, and Paraoxonase-3 Protein Levels in Palmitate- induced Non-alcoholic Fatty Liver Disease Model in HepG2 Cells
}

\author{
Palmitat ile Non-alkolik Yağlı Karaciğer Hastalığı Modeli Oluşturulan HepG2 Hücrelerinde \\ Rosmarinik Asitin Hücre Canlılığına, Yağlanmaya, Paraoksonaz-1 ve Paraoksonaz-3 Protein \\ Düzeylerine Etkisi
}

\author{
(D) Esra YAKŞi'1 ${ }^{1}$ (D) Eray ÖZGÜN² \\ 1 Lüleburgaz City Hospital, Kırklareli, Turkey \\ 2Trakya University Faculty of Medicine, Department of Medical Biochemistry, Edirne, Turkey
}

\begin{abstract}
Aim: We aimed to investigate the effect of rosmarinic acid (RA) on cell viability, steatosis, paraoxonase (PON)1, and PON3 protein levels in palmitate-induced non-alcoholic fatty liver disease (NAFLD) model in HepG2 cells.

Materials and Methods: To induce an experimental steatosis model, HepG2 cells were incubated with 1 mM palmitate for 24 hours. For the treatment, non-toxic RA concentrations were added to the cell culture medium simultaneously with the palmitate. Cell viability was evaluated by 3-(4,5-dimethyl-2-thiazolyl)-2,5-diphenyl-2H-tetrazolium bromide assay. To evaluate steatosis, intracellular triglyceride levels were measured and the cells were examined microscopically with Oil-Red 0 staining. PON1 and PON3 protein levels were measured by Western blotting.

Results: $1 \mathrm{mM}$ palmitate caused a significant decrease in cell viability and a significant increase in triglyceride levels, but it did not significantly change PON1 and PON3 protein levels. RA caused a significant increase in cell viability and a significant decrease in triglyceride levels in the palmitate-treated cells. Similar findings with the triglyceride levels of cells were shown in microscopic examination of cells that were stained with Oil-Red O. RA did not significantly change PON1 and PON3 protein levels in neither non-treated cells nor treated cells with palmitate.

Conclusion: Our study showed that RA increases cell viability and decreases steatosis, but it does not change PON1 and PON3 protein levels in palmitate-induced NAFLD model in HepG2 cells.
\end{abstract}

Keywords: Non-alcoholic fatty liver disease, rosmarinic acid, palmitate, paraoxonase-1, paraoxonase-3

ÖZ

Amaç: Palmitat ile non-alkolik yağlı karaciğer hastalığı modeli oluşturulan HepG2 hücrelerinde rosmarinik asitin (RA) hücre canlılığına, yağlanmaya, paraoksonaz (PON) 1 ve PON3 protein düzeylerine etkisini araştırmayı amaçladık.

Gereç ve Yöntem: Deneysel yağlanma modeli oluşturmak için, HepG2 hücreleri $1 \mathrm{mM}$ palmitat ile 24 saat inkübe edildi. Tedavi olarak palmitat ile aynı anda hücre kültürü medyumuna, HepG2 hücrelerine toksik olmayan RA konsantrasyonları eklendi. Hücre canlılığı 3-(4,5-dimetil-2-tiazolil)-2,5difenil-2H-tetrazolium bromür testi ile değerlendirildi. Yağlanmanın değerlendirilmesi için hücre içi trigliserid düzeyleri ölçüldü ve hücreler Oil-Red 0 ile boyanarak mikroskopik olarak incelendi. PON1 ve PON3 protein düzeyleri Western blot yöntemiyle ölçüldü.

Bulgular: $1 \mathrm{mM}$ palmitat hücre canlılığında anlamlı bir azalmaya ve trigliserid düzeylerinde anlamlı bir artışa yol açtı, PON1 ve PON3 protein düzeylerini ise anlamlı olarak değiştirmedi. Palmitat ile oluşturulan deneysel non-alkolik yağlı karaciğer hastalığı (NAFLD) modelinde RA, hücre canlılığını anlamlı olarak artırdı ve trigliserid düzeylerini anlamlı olarak azalttı. Oil-Red 0 ile boyanan hücrelerin mikroskopik incelenmelerinde

Address for Correspondence: Dr. Eray ÖZGÜN, Trakya University Faculty of Medicine, Department of Medical Biochemistry, Edirne, Turkey E-mail: drozgune@hotmail.com ORCID ID: orcid.org/0000-0002-6744-1519

Received: 03.11.2020 Accepted: 01.03.2021 
hücrelerin trigliserid düzeylerindeki değişimler ile benzer bulgular görüldü. RA hem palmitat uygulanmayan hem de palmitat uygulanan HepG2 hücrelerinde PON1 ve PON3 protein düzeylerini anlamlı olarak değiştirmedi.

Sonuç: Çalışmamız, RA'nın palmitat ile NAFLD modeli oluşturulan HepG2 hücrelerinde hücre canlılığını artırdığını, yağlanmayı azalttığını, ancak PON1 ve PON3 protein düzeylerini değiştirmediğini gösterdi.

Anahtar Kelimeler: Non-alkolik yağlı karaciğer hastalığı, rosmarinik asit, palmitat, paraoksanaz-1, paraoksonaz-3

\section{INTRODUCTION}

Non-alcoholic fatty liver disease (NAFLD) is a disease characterized by the presence of different degrees of fatty liver in individuals who do not have a habit of use of alcohol. NAFLD is one of the important health problems with its prevalence estimated to be around $25 \%$ worldwide. Triglyceride accumulation in hepatocytes is increased in NAFLD patients ${ }^{1,2}$. Palmitate, a 16-carbon saturated fatty acid, is found in the structure of triglycerides in the liver and is one of the most abundant fatty acids in the livers of both healthy individuals and NAFLD patients ${ }^{3}$.

NAFLD is not just a liver disease, but it is a multisystem disease. NAFLD has also been shown to be associated with metabolic syndrome and atherosclerosis $\mathrm{s}^{4,5}$. Paraoxonase (PON) 1 and PON3 enzymes are anti-atherogenic enzymes mainly synthesized in the liver. PON1 and PON3 are secreted from the liver into the circulation and are transported in the circulation bound to high-density lipoprotein (HDL) ${ }^{6}$.

HepG2 cells are commercially available human-derived hepatoma cells and are frequently used to induce an experimental NAFLD model with free fatty acids because of their similarity to hepatocytes ${ }^{7-10}$. It has been reported that the steatosis induced by $1 \mathrm{mM}$ palmitate in HepG2 cells is a cellular model of NAFLD that can be used to investigate acute and toxic effects in liver cells due to fat accumulation?

Rosmarinic acid (RA) is phenolic acid, the ester of caffeic acid and 3,4 dihydroxyphenyllactic acid synthesized from L-phenylalanine and L-tyrosine amino acids ${ }^{11}$. RA is a polyphenol found naturally in plants such as rosemary, sage, and perilla steak grass, with shown antioxidant and antiinflammatory effects $^{12}$. In the literature, we did not come across any study investigating the effect of RA on PON1 and PON3 enzymes.

In this study, it was aimed to investigate the effect of RA on cell viability, steatosis, PON1 and PON3 protein levels in palmitateinduced NAFLD model in human-derived hepatoma cells. With this study, the effect of RA on PON1 and PON3 levels both when administered directly and in NAFLD was shown for the first time.

\section{MATERIALS AND METHODS}

\section{Chemical and Consumables}

RA, sodium palmitate, 3-(4,5-dimethyl-2-thiazolyl)-2,5diphenyl-2H-tetrazolium bromide (MT) and Oil Red 0 were purchased from Sigma-Aldrich (St. Louis, MO, USA). Eagle's minimal essential mediums were purchased from Wisent (St-Bruno, QC, Canada). Fetal bovine serum (FBS), antibioticantimycotic and chemiluminescent substrate were purchased from Thermo Fisher (Waltham, MA, USA). Primary antibodies to PON1, PON3, and alpha tubulin and secondary antibodies were purchased from Abcam (Cambridge, England). Fatty acid-free bovine serum albumin was purchased from Gold Biotechnology (MO, USA). Radioimmunoprecipitation lysis buffer (RIPA) was purchased from Santa Cruz (Heidelberg, Germany). Polyvinylidene difluoride (PVDF) membrane was purchased from Bio-Rad (Hercules, CA, USA). All chemicals were of analytical purity.

\section{Cell Culture Applications}

This study was approved by Trakya University Deanship of Faculty of Medicine Scientific Research Ethics Committee on 29.03.2017 with the protocol code of TUTF-BAEK 2017/95 and decision number 06/05. Cells were kept in an incubator at $37{ }^{\circ} \mathrm{C}$ in $5 \% \mathrm{CO}_{2}$ with Eagle's minimum essential medium containing 10\% FBS and 1\% antibiotic-antimycotic. For the experiments, cells between passages of 10 and 20 were used.

HepG2 cells were incubated with $1 \mathrm{mM}$ palmitate for 24 hours to induce steatosis ${ }^{7-9}$. Sodium palmitate was dissolved in sterile water at $70{ }^{\circ} \mathrm{C}^{13,14}$ and conjugated for at least 3 hours 15 with $0.7 \mathrm{mM}$ fatty acid-free bovine serum albumin, which was dissolved in medium and its concentration was similar to human serum albumin concentrations and cells were incubated with mixture for 24 hours. In the control group, only medium containing $0.7 \mathrm{mM}$ albumin was applied.

\section{MTT Test}

$\mathrm{MTT}$ test was performed to assess cell viability ${ }^{16}$. $10^{4}$ cells were seeded in 96-well plates. RA alone and together with $1 \mathrm{mM}$ palmitate was applied to the cells at different concentrations for 24 hours. After 24 hours, the medium was removed and replaced with MTT $(5 \mathrm{mg} / \mathrm{mL})$ dissolved in $10 \mu \mathrm{L}$ of PBS and $100 \mu \mathrm{L}$ of Eagle's minimum essential medium without phenol red, and incubated for 4 hours. The medium containing MTT was taken and formazan, was dissolved with $200 \mu \mathrm{L}$ dimethyl sulfoxide and $25 \mu \mathrm{L}$ Sorenson buffer (0.1 M glycine and $0.1 \mathrm{M}$ sodium chloride; adjusted to $\mathrm{pH}$ : 10.5 with 0.1 $\mathrm{M}$ sodium hydroxide) and the resulting color was measured spectrophotometrically at 570/630 $\mathrm{nm}$ in a microplate reader ${ }^{17}$. 
The measured absorbances were divided by the mean of the control group on the same plate, and the results were given as a percentage of the control group.

\section{Triglyceride Measurement}

Cells were seeded into $25 \mathrm{~cm}^{2}$ flasks for triglyceride measurement. Different concentrations of RA were applied to the cells simultaneously with $1 \mathrm{mM}$ palmitate for 24 hours. After 24 hours, cells were washed with phosphate buffered saline (PBS) and then scraped with PBS buffer containing 1\% protease inhibitor and $0.1 \%$ Triton X-100. After homogenization using glass beads, the homogenate was centrifuged at 10,000 $\mathrm{g}$ for 10 minutes. The supernatant in the upper part was used in the experiments. Intracellular triglyceride levels were measured using the autoanalyzer's original kits. Protein levels were measured according to the method of Lowry et al. ${ }^{18}$, and triglyceride levels were divided to protein results and results of groups were given as fold of control by dividing the results to the mean value of control group.

\section{Oil Red 0 Staining}

For staining with Oil Red 0, cells were seeded in 6-well plates. Different concentrations of RA were applied to the cells simultaneously with $1 \mathrm{mM}$ palmitate for 24 hours. After 24 hours, cells were washed with PBS and fixed with 10\% paraformaldehyde. After fixation, it was washed with $60 \%$ isopropanol and incubated with 60\% isopropanol containing Oil Red 0 [stock 0.35\% (w/v) Oil Red 0 dissolved in 100\% isopropanol] and washed with distilled water and photographed under a phase contrast invert microscope using a microscope camera ${ }^{9}$.

\section{Western Blot Method}

Cells were seeded in $75 \mathrm{~cm}^{2}$ flasks. Different concentrations of RA were applied to the cells simultaneously with $1 \mathrm{mM}$ palmitate for 24 hours. After the experimental procedure, cells washed with PBS were scraped with RIPA containing 1\% of protease inhibitor cocktail, phenyl methyl sulfonyl fluoride and sodium orthovanadate solutions. After homogenization using glass beads, the homogenate was centrifuged at $10,000 \mathrm{~g}$ for 10 minutes. The supernatant in the upper part was used in the experiments. Protein measurement was performed according to the method of Lowry et al. ${ }^{18}$. A 4-12\% polyacrylamide gel was prepared according to the Laemmli ${ }^{19}$ method, and $20 \mu \mathrm{g}$ of protein was separated by vertical sodium dodecyl sulfatepolyacrylamide gel electrophoresis. Gels were transferred to a polyvinylidene difluoride membrane using a semi-wet transfer system. Membranes were blocked with 5\% milk powder for 1 hour and incubated with primary antibodies $(1: 1,000$ dilution for PON1 and PON3, 1:10,000 dilution of tubulin) overnight at $4{ }^{\circ} \mathrm{C}$. Then, membranes incubated for 1 hour with secondary antibody (1:10,000 dilution) were visualized using a chemiluminescent substrate. Band intensity for each protein was calculated using the Image J program ${ }^{20}$. PON1 and PON3 protein levels were divided to the level of alpha tubulin protein used as the loading control of the same sample, and the results were given as a fold of control by dividing value to the value of control group in the same membrane.

\section{Statistical Analysis}

Statistical analyzes were performed using the Statistical Package for the Social Sciences 20 program. One-way ANOVA was used to compare experimental parameters, and Tukey and Tamhane tests were used for comparison between groups. Results were expressed as mean \pm standard deviation, and $p<0.05$ was considered statistically significant.

\section{RESULTS}

Cell viabilities after RA treatment to HepG2 cells for 24 hours were found as: $100 \pm 3$ in the control group, $96 \pm 6 \%$ in cells treated with $5 \mu \mathrm{M}$ RA, $106 \pm 8 \%$ in cells treated with $10 \mu \mathrm{M}$ RA, $107 \pm 6 \%$ in cells treated with $25 \mu \mathrm{M}$ RA, $122 \pm 9 \%$ in cells treated with $50 \mu \mathrm{M}$ RA, $131 \pm 8 \%$ in cells treated with 100 $\mu \mathrm{M}$ RA, $119 \pm 8 \%$ in cells treated with $200 \mu \mathrm{M}$ RA, $77 \pm 7 \%$ in cells treated with $300 \mu \mathrm{M}$ RA, $73 \pm 5 \%$ in cells treated with $400 \mu \mathrm{M}$ RA, and $68 \pm 6 \%$ in cells treated with $500 \mu \mathrm{M}$ RA. 5, 10 and $25 \mu \mathrm{M}$ RA did not significantly change cell viability compared to the control group ( $p>0.05$ for all). 50, 100 and $200 \mu \mathrm{M}$ RA significantly increased cell viability compared to the control group, 5, 10 and $25 \mu \mathrm{M}$ RA ( $<<0.05$ for all). $200 \mu \mathrm{M}$ RA significantly decreased cell viability compared to $100 \mu \mathrm{M}$ RA ( $p<0.05)$. 300, 400 and $500 \mu M$ RA significantly decreased

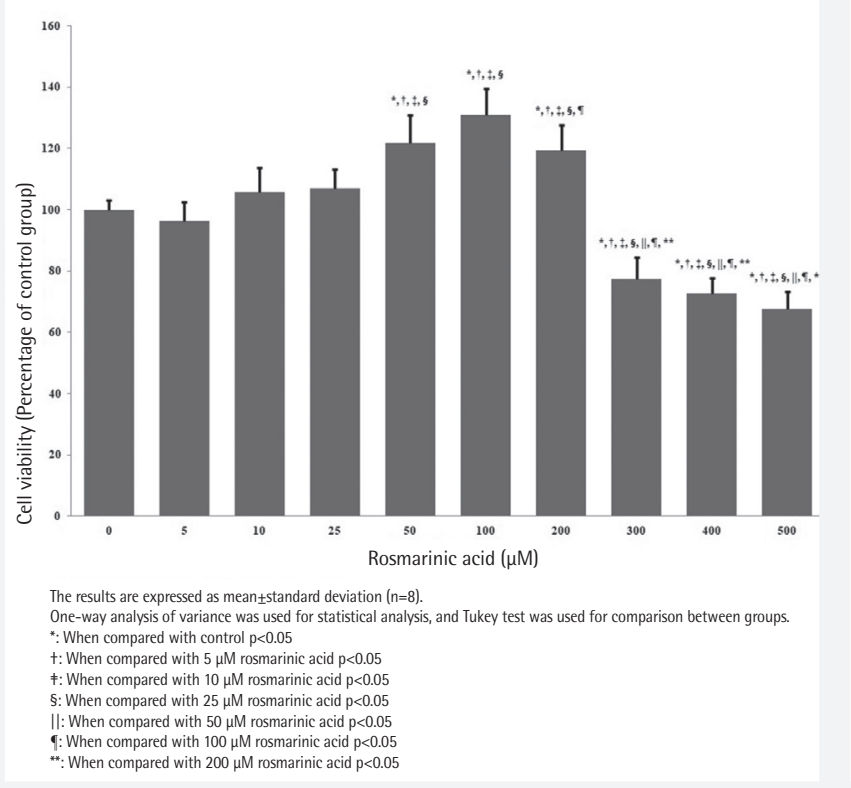

Figure 1. Effect of rosmarinic acid on cell viability in HepG2 cells 
cell viability compared to control and 5, 10, 25, 50, 100 and $200 \mu$ M RA ( $p<0.05$ for all) (Figure 1).

Cell viabilities after 24 hours treatment to HepG2 cells were found as: $100 \pm 6 \%$ in the control group, $54 \pm 4 \%$ in cells treated with only $1 \mathrm{mM}$ palmitate; $54 \pm 6 \%$ in cells treated with $1 \mathrm{mM}$ palmitate and $5 \mu \mathrm{M}$ RA, $55 \pm 6 \%$ in cells treated with $10 \mu \mathrm{M}$ RA, $59 \pm 6 \%$ in cells treated with $25 \mu \mathrm{M}$ RA, $66 \pm 6 \%$ in cells treated with $50 \mu \mathrm{M} \mathrm{RA}, 75 \pm 7 \%$ in cells treated with $100 \mu \mathrm{M}$ RA and $83 \pm 5 \%$ in cells treated with $200 \mu \mathrm{M}$ RA. Cell viability was significantly reduced in all cells treated with $1 \mathrm{mM}$ palmitate compared to the control group ( $p<0.05$ for all). Treatment of $50 \mu \mathrm{M}$ RA with $1 \mathrm{mM}$ palmitate significantly increased cell viability compared to treatment of only $1 \mathrm{mM}$ palmitate and 5 and $10 \mu \mathrm{M}$ RA with $1 \mathrm{mM}$ palmitate ( $\mathrm{p}<0.05$ for all). Treatment of $100 \mu \mathrm{M}$ RA with $1 \mathrm{mM}$ palmitate significantly increased cell

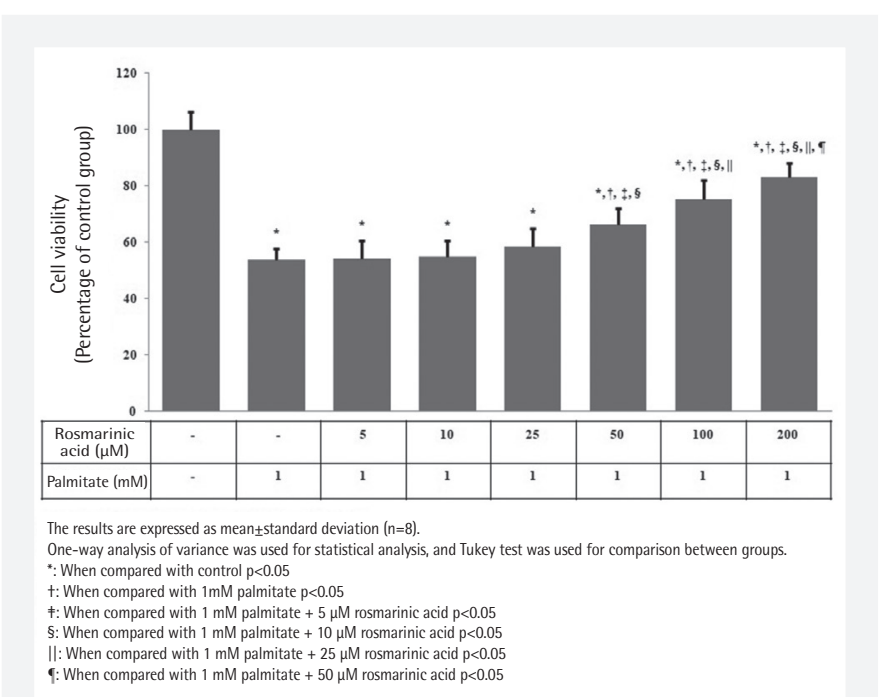

Figure 2. The effect of rosmarinic acid on cell viability in palmitate-induced steatosis in HepG2 cells

viability compared to treatment of only $1 \mathrm{mM}$ palmitate and 5, 10, and $25 \mu \mathrm{M}$ RA with $1 \mathrm{mM}$ palmitate ( $p<0.05$ for all). Treatment of $200 \mu \mathrm{M}$ RA with $1 \mathrm{mM}$ palmitate significantly increased cell viability compared to treatment of only $1 \mathrm{mM}$ palmitate and 5, 10, 25 and $50 \mu \mathrm{M}$ RA with $1 \mathrm{mM}$ palmitate $(\mathrm{p}<0.05$ for all) (Figure 2).

Triglyceride levels after 24 hours treatment to HepG2 cells were found as $1.00 \pm 0.07$ in the control group, $2.54 \pm 0.06$ in cells treated with only $1 \mathrm{mM}$ palmitate; $2.55 \pm 0.04$ in cells treated with $1 \mathrm{mM}$ palmitate and $5 \mu \mathrm{M}$ RA, $2.47 \pm 0.12$ in cells treated with $1 \mathrm{mM}$ palmitate and $10 \mu \mathrm{M}$ RA $2.44 \pm 0.15$ in cells treated with $1 \mathrm{mM}$ palmitate and $25 \mu \mathrm{M}$ RA $2.27 \pm 0.05$ in cells treated with $1 \mathrm{mM}$ palmitate and $50 \mu \mathrm{M}$ RA $1.94 \pm 0.17$ in cells treated with $1 \mathrm{mM}$ palmitate and $100 \mu \mathrm{M}$ RA and $1.77 \pm 0.27$ in cells treated with $1 \mathrm{mM}$ palmitate and $200 \mu \mathrm{M}$ RA. Triglyceride levels increased significantly in all cells treated with $1 \mathrm{mM}$ palmitate compared to the control group ( $\mathrm{p}<0.05$ for all). Treatment of 50 $\mu \mathrm{M}$ RA with $1 \mathrm{mM}$ palmitate significantly reduced triglyceride levels compared to treatment of only $1 \mathrm{mM}$ palmitate and treatment of $5 \mu \mathrm{M}$ RA with $1 \mathrm{mM}$ palmitate ( $p<0.05$ for both). Treatment of $100 \mu \mathrm{M}$ RA with $1 \mathrm{mM}$ palmitate significantly reduced triglyceride levels compared to administration of only $1 \mathrm{mM}$ palmitate and administration of 5,10 , and $25 \mu \mathrm{M}$ RA with $1 \mathrm{mM}$ palmitate ( $<<0.05$ for all). Treatment of $200 \mu \mathrm{M}$ RA with $1 \mathrm{mM}$ palmitate significantly reduced triglyceride levels compared to treatment of only $1 \mathrm{mM}$ palmitate and treatment of 5,10 , and $25 \mu \mathrm{M}$ RA with $1 \mathrm{mM}$ palmitate $(\mathrm{p}<0.05$ for all) (Figure 3A).

The effect of RA on steatosis was examined microscopically by Oil Red 0 staining in HepG2 cells, in which palmitate steatosis was created. It was observed that the staining with oil red 0 was higher in the cells treated with $1 \mathrm{mM}$ palmitate compared to the control group. It was observed that RA concentrations applied together with $1 \mathrm{mM}$ palmitate reduced staining with Oil Red 0 , and this decrease was more pronounced especially at higher concentrations (Figure 3B).

PON1 protein levels after RA treatment to HepG2 cells for 24 hours were: $1.11 \pm 0.13$ fold of control in cells treated with 100 $\mu \mathrm{M} R A$, and $1.07 \pm 0.07$ fold of control in cells treated with 200 $\mu M$ RA. PON3 protein levels after 24 hours treatment to HepG2 cells were: $1.12 \pm 0.16$ fold of control in cells treated with 100 $\mu \mathrm{M}$ RA and $1.25 \pm 0.28$ fold of control in cells treated with 200 $\mu \mathrm{M}$ RA. There was no significant difference in PON1 and PON3 levels between $100 \mu \mathrm{M}$ and $200 \mu \mathrm{M}$ RA treated and control cells ( $p>0.05$ for all) (Figure 4A).

After RA treatment to HepG2 cells with $1 \mathrm{mM}$ palmitate for 24 hours, PON1 levels were $0.94 \pm 0.05$ fold of control group in cells treated with only $1 \mathrm{mM}$ palmitate; it was found to be $1.01 \pm 0.10$ fold of control group in cells treated with 1 $\mathrm{mM}$ palmitate and $100 \mu \mathrm{M} \mathrm{RA}$, and $0.92 \pm 0.05$ fold of control group in cells treated with $200 \mu \mathrm{M}$ RA. PON3 levels were $1.03 \pm 0.11$ fold of control group in cells treated with only 1 $\mathrm{mM}$ palmitate; it was found to be $0.95 \pm 0.08$ fold of control group in cells treated with $1 \mathrm{mM}$ palmitate and $100 \mu \mathrm{M} R \mathrm{~A}_{\text {, }}$ and $1.04 \pm 0.17$ fold of control group in cells treated with 200 $\mu \mathrm{M}$ RA. There was no significant difference in PON1 and PON3 protein levels between treatment of $1 \mathrm{mM}$ palmitate, $100 \mu \mathrm{M}$ and $200 \mu \mathrm{M}$ RA with $1 \mathrm{mM}$ palmitate and control cells ( $p>0.05$ for all) (Figure 4B).

\section{DISCUSSION}

NAFLD is a multisystemic disease whose effects are not limited to the liver and is an important health problem with an increasing incidence all over the world ${ }^{4,21}$. NAFLD is an 


\section{A)}

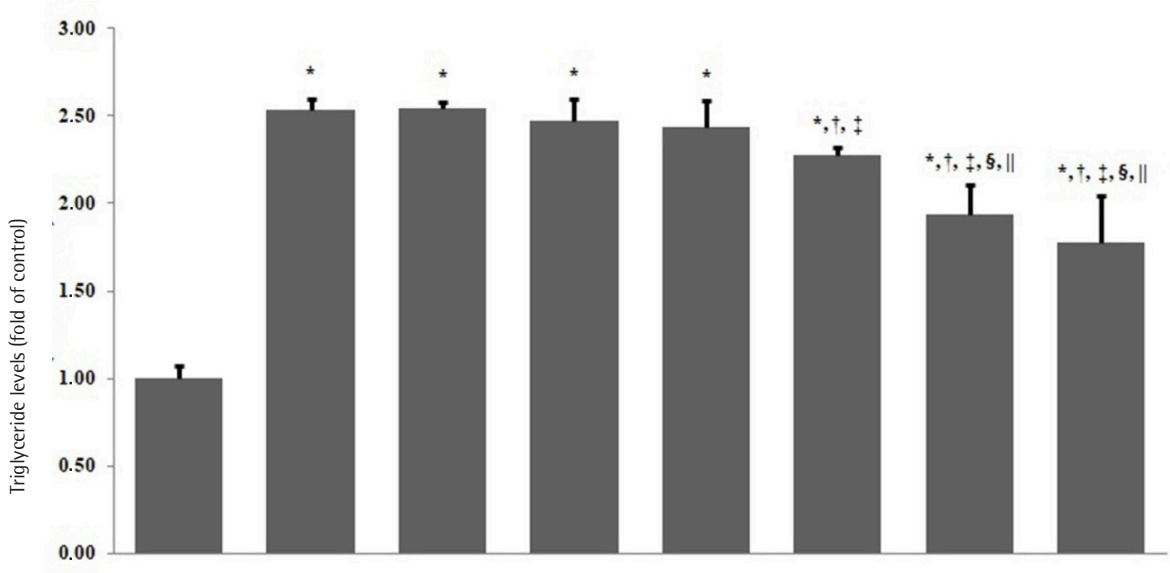

\begin{tabular}{|c|c|c|c|c|c|c|c|c|}
\hline $\begin{array}{c}\text { Rosmarinic acid } \\
(\mu \mathrm{M})\end{array}$ & - & - & 5 & 10 & 25 & 50 & 100 & 200 \\
\hline $\begin{array}{c}\text { Palmitate } \\
(\mathrm{mM})\end{array}$ & - & 1 & 1 & 1 & 1 & 1 & 1 & 1 \\
\hline
\end{tabular}

Six different results of 3 independent experiments in each group are expressed as mean \pm standard deviation.

One-Way Analysis of Variance was used for statistical analysis, and Tamhane test was used for comparison between groups.

*: When compared with control $p<0.05$

$\mathrm{t}$ : When compared with $1 \mathrm{mM}$ palmitate $p<0.05$

¥: When compared with $1 \mathrm{mM}$ palmitate $+5 \mu \mathrm{M}$ rosmarinic acid $p<0.05$

$\S$ : When compared with $1 \mathrm{mM}$ palmitate $+10 \mu \mathrm{M}$ rosmarinic acid $\mathrm{p}<0.05$

II: When compared with $1 \mathrm{mM}$ palmitate $+25 \mu \mathrm{M}$ rosmarinic acid $p<0.05$

B)

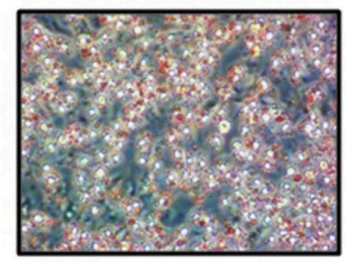

Control

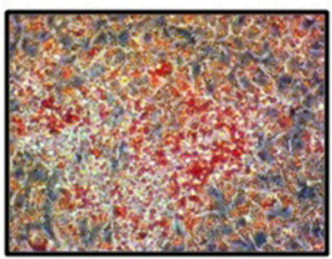

$1 \mathrm{mM}$ palmitate $+25 \mu \mathrm{M}$ rosmarinic acid

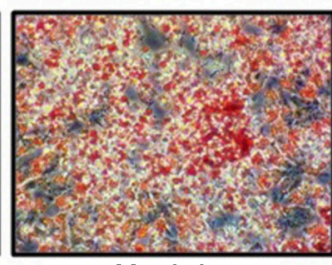

$1 \mathrm{mM}$ palmitate

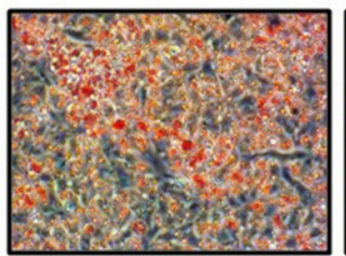

$1 \mathrm{mM}$ palmitate $+50 \mu \mathrm{M}$ rosmarinic acid

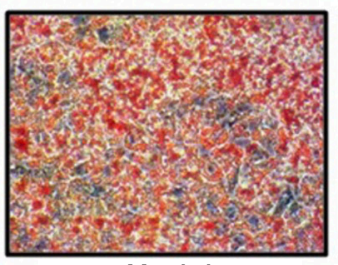

$1 \mathrm{mM}$ palmitate $+5 \mu \mathrm{M}$ rosmarinic acid

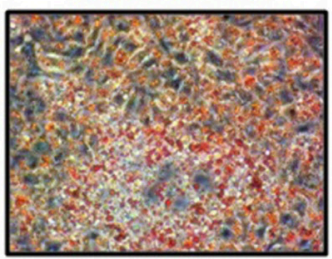

$1 \mathrm{mM}$ palmitate $+100 \mu \mathrm{M}$ rosmarinic acid

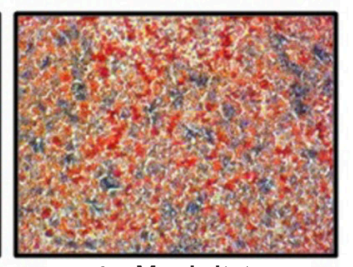

$1 \mathrm{mM}$ palmitate $+10 \mu \mathrm{M}$ rosmarinic acid

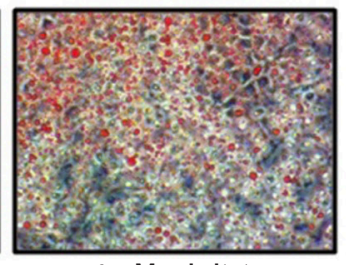

$1 \mathrm{mM}$ palmitate $+200 \mu \mathrm{M}$ rosmarinic acid

Figure 3. The effect of rosmarinic acid on A) triglyceride levels and B) steatosis (Oil Red 0 staining, 400x magnification) in palmitateinduced steatosis in HepG2 cells

independent risk factor for atherogenic dyslipidemia and has also been shown to be associated with atherosclerosis ${ }^{2,5}$. Although diet and exercise are recommended primarily in the treatment of NAFLD, it has been reported that antioxidant

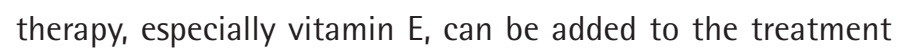
in these patients ${ }^{1,22}$. RA is a plant-derived polyphenol that protects against oxidative damage and scavenges free radicals $^{12,23}$. The most common cause of death in NAFLD patients is cardiovascular diseases ${ }^{24}$. PON1 and PON3 enzymes are antioxidant enzymes mainly synthesized in the liver. These enzymes take part in the structure of HDL in the circulation and play a role in preventing the development of atherosclerosis ${ }^{6}$.

The aim of our study was to investigate the effect of RA on cell viability, steatosis, PON1 and PON3 protein levels in palmitateinduced experimental NAFLD model in HepG2 cells.

There are conflicting results in the literature regarding the effect of RA on cell viability in HepG2 cells. Adomako-Bonsu et al. ${ }^{25}$ reported that RA applied to HepG2 cells for 5 hours was not toxic up to $700 \mu \mathrm{M}$ and caused $25 \%$ toxicity at $2800 \mu \mathrm{M}$ 


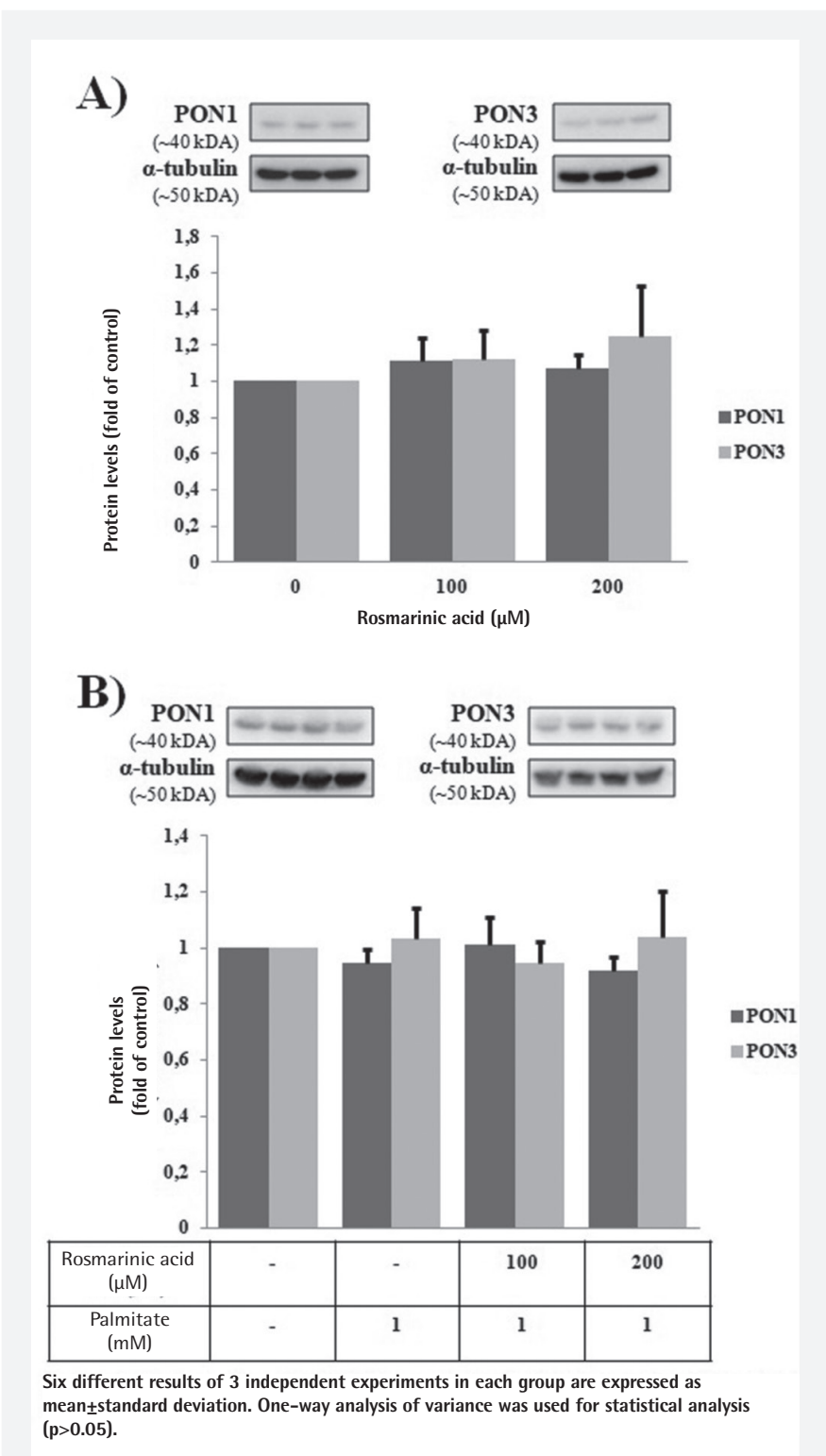

Figure 4. Effect of rosmarinic acid on levels of paraoxonase 1 and 3 when, A) administered alone and B) combined with $1 \mathrm{mM}$ palmitate to HepG2 cells

concentration; Wu et al. ${ }^{26}$ reported that $160 \mu \mathrm{M}$ RA applied to HepG2 cells for 24 or 48 hours was not toxic. Ozgun and Ozgun ${ }^{27}$ reported that $100 \mu \mathrm{M}$ RA applied to HepG2 cells for 24 hours did not cause a decrease in cell viability, while $1000 \mu \mathrm{M}$ RA reduced cell viability by more than $50 \%$. On the other hand, Ma et al. ${ }^{28}$ reported that approximately $35 \mu \mathrm{M}$ of RA applied to HepG2 cells for 24 hours reduced cell viability. For this reason, in our study, the effect of RA on cell viability was investigated by applying RA concentrations up to $500 \mu \mathrm{M}$ to HepG2 cells for 24 hours. While 50, 100 and $200 \mu \mathrm{M}$ RA significantly increased cell viability in HepG2 cells, RA concentrations of $300 \mu \mathrm{M}$ and above significantly decreased cell viability, and therefore RA concentrations up to $200 \mu \mathrm{M}$ were applied against palmitate- induced steatosis.

It is known that in the palmitate-induced cellular NAFLD model in HepG2 cells, cell viability decreases and intracellular steatosis increases ${ }^{7.8}$. In our study, palmitate application significantly decreased cell viability and increased intracellular triglyceride level, which was consistent with the literature. It was also seen microscopically that palmitate application increased the intracellular lipid content. These findings prove that palmitate-induced cellular NAFLD model are formed in HepG2 cells in our study.

In our study, 50, 100 and $200 \mu \mathrm{M}$ RA significantly reduced palmitate-induced cell death. In the literature, we could not find any study investigating the effect of RA on cell viability in the palmitate-induced cellular NAFLD model, but in a different experimental model that supports our findings, it has been reported that RA reduces tert-butyl hydroperoxideinduced cell death in HepG2 cells depending on the dose ${ }^{29}$. In our study, 50, 100 and $200 \mu \mathrm{M}$ RA significantly reduced the increase in triglyceride levels caused by palmitate, and it was also seen microscopically with Oil Red 0 staining that RA reduced steatosis, especially at high doses. We found only one study investigating the effect of RA on palmitate-induced experimental steatosis, and in this study published in 2020, Kim et al. ${ }^{10}$ reported that RA reduced the steatosis induced by $500 \mu \mathrm{M}$ palmitate, in line with our study.

In our study, $1 \mathrm{mM}$ palmitate administration in HepG2 cells did not significantly change PON1 and PON3 protein levels. In the literature, Özgün et al. ${ }^{8}$ supportive of our study, reported that palmitate administration to HepG2 cells, in which an experimental NAFLD model was created with $1 \mathrm{mM}$ palmitate, did not change PON1 and PON3 protein levels. At the same time, Kudchodkar et al. ${ }^{30}$ reported that dietary tripalmitin did not change PON1 activity in rats, while Boshtam et al. ${ }^{31}$ reported that there was no difference between palmitic acid content of HDL and PON1 activities.

There is no study in the literature investigating the effect of RA on PON1 or PON3 enzymes. In our study, 100 and $200 \mu \mathrm{M}$ RA, the most effective doses on cell viability and intracellular steatosis, had no significant effect on PON1 and PON3 protein expressions both directly in HepG2 cells and in the palmitateinduced cellular NAFLD model in HepG2 cells. In the light of these findings, we can say that RA has no significant effect on PON1 and PON3 protein levels in HepG2 cells, neither when administered alone nor in combination with palmitate.

\section{Study Limitations}

Examination of the effects of RA only at the cellular level since it is an in vitro experimental study, experimental NAFLD model's being limited to 24 hours to avoid serum starvation in cells as stated in the literature, and the use of HepG2 cell line 
instead of primary hepatocytes, although it is frequently used in the literature, are the limitations of this study.

\section{CONCLUSION}

Our study showed that RA increased cell viability and decreased steatosis, but did not change PON1 and PON3 protein levels in the palmitate-induced cellular NAFLD model in human hepatoma cells. In the light of our findings, we can say that RA may be effective in the prevention of NAFLD because it reduces steatosis, but it has no effect on the levels of antiatherogenic enzymes PON1 and PON3. However, our study is an in vitro experimental study and our findings should be supported by future animal and human studies.

\section{Ethics}

Ethics Committee Approval: This study was approved by Trakya University Deanship of Faculty of Medicine Scientific Research Ethics Committee on 29.03.2017 with the protocol code of TUTF-BAEK 2017/95 and decision number 06/05.

Informed Consent: Commercially available HepG2 cells were used in this study.

Peer-review: Externally and internally peer-reviewed.

\section{Authorship Contributions}

Surgical and Medical Practices: E.Y., E.Ö., Concept: E.Y., E.Ö., Design: E.Y., E.Ö., Data Collection or Processing: E.Y., E.Ö., Analysis or Interpretation: E.Y., E.Ö., Literature Search: E.Y., E.Ö., Writing: E.Y., E.Ö.

Conflict of Interest: No conflict of interest was declared by the authors.

Financial Disclosure: This study was supported by Trakya University Scientific Research Projects Unit (TUBAP) with project number TUBAP-2017/134 and was produced from Esra YAKŞi's master's thesis completed at Trakya University Health Sciences Institute. The data of this study were presented as an oral presentation at the International Medical and Health Sciences Research Congress held in Bandırma/Turkey in 2019. We thank TUBAP and Trakya University Technology Research and Development Application and Research Center where chemiluminescence imaging was performed.

\section{References}

1. Chalasani N, Younossi Z, Lavine JE, Diehl AM, Brunt EM, Cusi $K$, et al. The diagnosis and management of non-alcoholic fatty liver disease: practice Guideline by the American Association for the Study of Liver Diseases, American College of Gastroenterology, and the American Gastroenterological Association. Hepatology. 2012;55:2005-23.

2. DeFilippis AP, Blaha MJ, Martin SS, Reed RM, Jones SR, Nasir K, et al. Nonalcoholic fatty liver disease and serum lipoproteins: the Multi-Ethnic Study of Atherosclerosis. Atherosclerosis. 2013;227:429-36.
3. Araya J, Rodrigo R, Videla LA, Thielemann L, Orellana M, Pettinelli $P$ et al. Increase in long-chain polyunsaturated fatty acid $n-6 / n-3$ ratio in relation to hepatic steatosis in patients with non-alcoholic fatty liver disease. Clin Sci (Lond). 2004;106:635-43.

4. Byrne CD, Targher G. NAFLD: a multisystem disease. J Hepatol. 2015;62(1 Suppl):47-64.

5. Sookoian S, Pirola CJ. Non-alcoholic fatty liver disease is strongly associated with carotid atherosclerosis: a systematic review. J Hepatol. 2008;49:600-7.

6. Précourt LP, Amre D, Denis MC, Lavoie JC, Delvin E, Seidman E, et al. The three-gene paraoxonase family: physiologic roles, actions and regulation. Atherosclerosis. 2011;214:20-36.

7. Gómez-Lechón MJ, Donato MT, Martínez-Romero A, Jiménez N, Castell JV, O'Connor JE. A human hepatocellular in vitro model to investigate steatosis. Chem Biol Interact. 2007;165:106-16.

8. Özgün GS, Özgün E, Tabakçığlu K, Gökmen SS, Eskiocak S. Effect of palmitate-induced steatosis on paraoxonase-1 and paraoxonase-3 enzymes in human-derived liver (HepG2) cells. Archives of Clinical and Experimental Medicine. 2019;4:118-21.

9. Jang E, Shin MH, Kim KS, Kim Y, Na YC, Woo HJ, et al. Anti-lipoapoptotic effect of Artemisia capillaris extract on free fatty acids-induced HepG2 cells. BMC Complement Altern Med. 2014;14:253.

10. Kim M, Yoo G, Randy A, Son YJ, Hong CR, Kim SM, et al. Lemon Balm and Its Constituent, Rosmarinic Acid, Alleviate Liver Damage in an Animal Model of Nonalcoholic Steatohepatitis. Nutrients. 2020;12:1166.

11. Bulgakov VP, Inyushkina YV, Fedoreyev SA. Rosmarinic acid and its derivatives: biotechnology and applications. Crit Rev Biotechnol. 2012;32:203-17.

12. Kim GD, Park YS, Jin YH, Park CS. Production and applications of rosmarinic acid and structurally related compounds. Appl Microbiol Biotechnol. 2015;99:2083-92.

13. Park JY, Kim Y, Im JA, Lee H. Oligonol suppresses lipid accumulation and improves insulin resistance in a palmitate-induced in HepG2 hepatocytes as a cellular steatosis model. BMC Complement Altern Med. 2015;15:185.

14. Xu S, Nam SM, Kim JH, Das R, Choi SK, Nguyen TT, et al. Palmitate induces ER calcium depletion and apoptosis in mouse podocytes subsequent to mitochondrial oxidative stress. Cell Death Dis. 2015;6:e1976.

15. Yang $X$, Chan $C$. Repression of PKR mediates palmitate-induced apoptosis in HepG2 cells through regulation of Bcl-2. Cell Res. 2009;19:469-86.

16. Mosmann T. Rapid colorimetric assay for cellular growth and survival: application to proliferation and cytotoxicity assays. J Immunol Methods. 1983;65:55-63

17. Ahmadian S, Barar J, Saei AA, Fakhree MA, Omidi Y. Cellular toxicity of nanogenomedicine in MCF-7 cell line: MTT assay. J Vis Exp. 2009;(26):1191.

18. Lowry $\mathrm{OH}$, Rosebrough NJ, Farr $\mathrm{AL}$, Randall RJ. Protein measurement with the Folin phenol reagent. J Biol Chem. 1951;193:265-75.

19. Laemmli UK. Cleavage of structural proteins during the assembly of the head of bacteriophage T4. Nature. 1970;227:680-5.

20. Schneider CA, Rasband WS, Eliceiri KW. NIH Image to ImageJ: 25 years of image analysis. Nat Methods. 2012;9:671-5.

21. Younossi ZM, Koenig AB, Abdelatif D, Fazel Y, Henry L, Wymer M. Global epidemiology of nonalcoholic fatty liver disease-Meta-analytic assessment of prevalence, incidence, and outcomes. Hepatology. 2016;64:73-84.

22. Review Team, LaBrecque DR, Abbas $Z$, Anania F, Ferenci $P$, Khan AG, et al. World Gastroenterology Organisation global guidelines: Nonalcoholic fatty liver disease and nonalcoholic steatohepatitis. J Clin Gastroenterol. 2014;48:467-73.

23. Pérez-Fons L, Garzón MT, Micol V. Relationship between the antioxidant capacity and effect of rosemary (Rosmarinus officinalis L.) polyphenols on membrane phospholipid order. J Agric Food Chem. 2010;58:161-71. 
24. Polimeni L, Del Ben M, Baratta F, Perri L, Albanese F, Pastori D, et al. Oxidative stress: New insights on the association of non-alcoholic fatty liver disease and atherosclerosis. World J Hepatol. 2015;7:1325-36.

25. Adomako-Bonsu AG, Chan SL, Pratten M, Fry JR. Antioxidant activity of rosmarinic acid and its principal metabolites in chemical and cellular systems: Importance of physico-chemical characteristics. Toxicol In Vitro. 2017;40:248-55

26. Wu J, Zhu Y, Li F, Zhang G, Shi J, Ou R, et al. Spica prunellae and its marker compound rosmarinic acid induced the expression of efflux transporters through activation of Nrf2-mediated signaling pathway in HepG2 cells. J Ethnopharmacol. 2016;193:1-11.

27. Ozgun GS, Ozgun E. The cytotoxic concentration of rosmarinic acid increases MG132-induced cytotoxicity, proteasome inhibition, autophagy, cellular stresses, and apoptosis in HepG2 cells. Hum Exp Toxicol. 2020;39:514-23.
28. Ma ZJ, Yan H, Wang YJ, Yang Y, Li XB, Shi AC, et al. Proteomics analysis demonstrating rosmarinic acid suppresses cell growth by blocking the glycolytic pathway in human HepG2 cells. Biomed Pharmacother. 2018;105:334-49.

29. Lima CF, Fernandes-Ferreira M, Pereira-Wilson C. Phenolic compounds protect HepG2 cells from oxidative damage: relevance of glutathione levels. Life Sci. 2006;79:2056-68.

30. Kudchodkar BJ, Lacko AG, Dory L, Fungwe TV. Dietary fat modulates serum paraoxonase 1 activity in rats. J Nutr. 2000;130:2427-33.

31. Boshtam M, Razavi AE, Pourfarzam M, Ani M, Naderi GA, Basati G, et al. Serum paraoxonase 1 activity is associated with fatty acid composition of high density lipoprotein. Dis Markers. 2013;35:273-80. 